\title{
Scalable Synthesis, In Vitro cccDNA Reduction, and In Vivo Antihepatitis B Virus Activity of a Phosphonomethoxydeoxythreosyl Adenine Prodrug
}

Min Luo, Shuo Wu, Raj Kalkeri, Roger G. Ptak, Tianlun Zhou, Lieve Van Mellaert, Chuanmin Wang, Shrinivas G. Dumbre, Timothy Block, Elisabetta Groaz, Steven De Jonghe, Yuhuan Li, and Piet Herdewijn*

Cite This: https://dx.doi.org/10.1021/acs.jmedchem.0c01381

Read Online

\section{ACCESS | Lلll Metrics \& More | 回 Article Recommendations | S1 Supporting Information}

ABSTRACT: Standard literature procedures for the chemical synthesis of L-threose nucleosides generally employ L-ascorbic acid as starting material. Herein, we have explored two alternative routes that start from either L-arabitol or L-diethyl tartrate, both affording 2-O-methyl-L-threofuranose as a key building block for nucleobase incorporation. The access to multigram quantities of this glycosyl donor in a reproducible fashion allows for the preparation of $2^{\prime}$-deoxy- $\alpha$-L-threofuranosyl phosphonate nucleosides on a large scale. This methodology was applied to the gram scale synthesis of an aryloxy amidate prodrug of phosphonome-

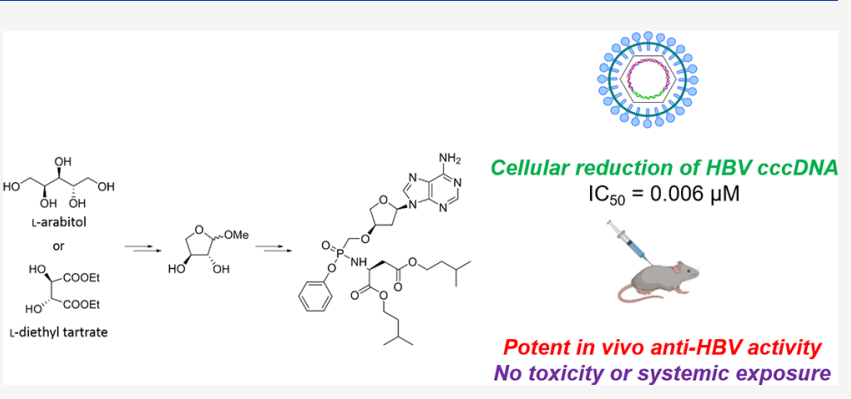
thoxydeoxythreosyl adenine. This prodrug exerted potent activity against an entecavir-resistant hepatitis B virus (HBV) strain, while leading to a significant reduction in the levels of HBV covalently closed circular DNA in a cellular assay. Furthermore, its remarkable anti-HBV efficacy was also confirmed in vivo using a hydrodynamic injection-based HBV mouse model, without relevant toxicity and systemic exposure occurring.

\section{INTRODUCTION}

Chronic infection due to hepatitis B virus (HBV) is a global health problem affecting approximately 257 million people, which is likely to continue increasing in the coming decades, particularly in developing countries. ${ }^{1,2}$ This contagious liver disease often correlates with a high risk of developing lifethreatening complications such as cirrhosis and hepatocellular carcinoma, sometimes leaving liver transplantation as the only treatment option for infected individuals. ${ }^{3}$ Presently approved treatments for $\mathrm{HBV}$ infection include interferon-based immunotherapy as well as the use of antiviral nucleoside analogues [lamivudine, entecavir (ETV), and telbivudine] and acyclic nucleoside phosphonate prodrugs [adefovir dipivoxil, tenofovir disoproxil, and tenofovir alafenamide (TAF, Figure 1)]. ${ }^{4}$ However, none of the available drugs allow for HBV eradication, mainly because of the unique replication mechanism of this virus. ${ }^{5}$ Upon hepatocyte infection, the partially double-stranded viral DNA genome matures into a covalently closed circular DNA (cccDNA) located in the nucleus, which serves as a template for the reverse transcription of an RNA intermediate occurring in the cytoplasm. Therefore, in the continuing search for novel antiviral drug candidates that could inhibit HBV with improved efficacy and safety, it is important to identify compounds able not only to inhibit the viral reverse transcriptase but also affect the pool of

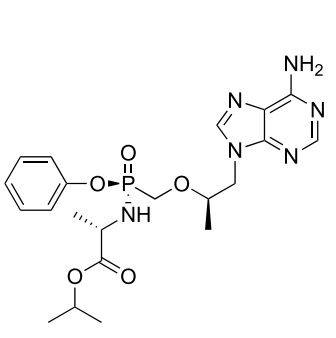

Tenofovir alafenamide (TAF)

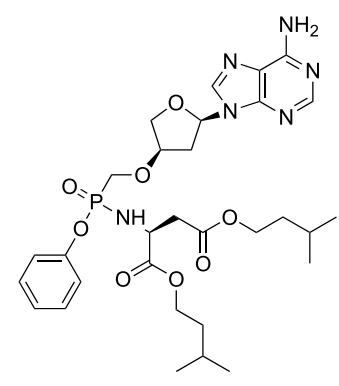

Figure 1. Structure of TAF and phosphonomethoxydeoxythreosyl adenine prodrug $\mathbf{1}$ investigated in this study.

nuclear cccDNA molecules, which are responsible for HBV persistence and reactivation. 6 ,7

A particularly interesting class of nucleoside analogues are built on a 2-deoxythreose sugar ring, ${ }^{8}$ especially those

Received: August 6, 2020 
derivatized at the $3^{\prime}-\mathrm{OH}$ position with a phosphonomethoxy functionality. Among these analogues, phosphonomethoxydeoxythreosyl adenine (PMDTA) and phosphonomethoxydeoxythreosyl thymine emerged as potent inhibitors of the replication of human immunodeficiency virus (HIV) and HBV without concomitant cytotoxicity. ${ }^{9,10}$ A number of aryloxy phosphonoamidate and phosphonobisamidate PMDT prodrugs were also synthesized, leading to a significant enhancement in antiviral activity against HIV and HBV. Specifically, compound 1 (Figure 1), which is the L-aspartic acid diisoamylester prodrug of PMDTA, was identified as a promising anti-HBV candidate with $\mathrm{EC}_{50}$ and $\mathrm{EC}_{90}$ values of 0.01 and $0.98 \mu \mathrm{M},{ }^{10}$ respectively, thus warranting further in-depth biological investigation both in vitro and in vivo. These preclinical efficacy and toxicity studies require large amounts of compound 1. Preferentially, such a compound should be obtained in a few high yielding steps, without the need of cumbersome chromatographic purification procedures. Therefore, we decided to compare different synthetic routes that could be amenable to the large-scale synthesis of $2^{\prime}$ deoxythreose nucleosides and especially expand access to the desired prodrug 1. In particular, we elaborated two distinct synthetic schemes starting from inexpensive and commercially available L-arabitol and L-diethyl tartrate toward a versatile Lthreonolactone synthon as alternatives to the previously and routinely used L-ascorbic acid approach. ${ }^{10}$ Given the abovementioned broad array of applications of threose nucleoside derivatives as both antiviral drugs and constituents of oligonucleotides, such synthetic optimization constitutes a generally useful endeavor. With compound $\mathbf{1}$ in hand, a followup study of its anti-HBV profile was then undertaken, the details of which are reported below.

\section{RESULTS AND DISCUSSION}

Chemical Synthesis Studies. The first synthesis of an Lthreose nucleoside was described in 1967 by Murry and Prokop beginning with L-arabitol. ${ }^{11}$ However, the most popular starting compound for the preparation of the Lthreonolactone (and its lactol) sugar that serves as a key precursor to L-threose nucleoside analogues is L-ascorbic acid. $^{12-15}$ This pathway was first optimized for large scale production by Eschenmoser and coworkers, ${ }^{16,17}$ and later by the Chaput group ${ }^{18}$ (Scheme 1). Owing to our interest in the phosphonate analogues of threose nucleosides, we previously reported the regioselective protection of the $2-\mathrm{OH}$ group of 3 to furnish 2-O-benzoylated lactone 5 as a precursor of glycosyl acetate 6, which was used for the synthesis of PMDT analogues including compound $\mathbf{1} .^{19}$

Scheme 1. Reported Synthesis of Glycosyl Donors 4 and 6 from L-ascorbic Acid 2

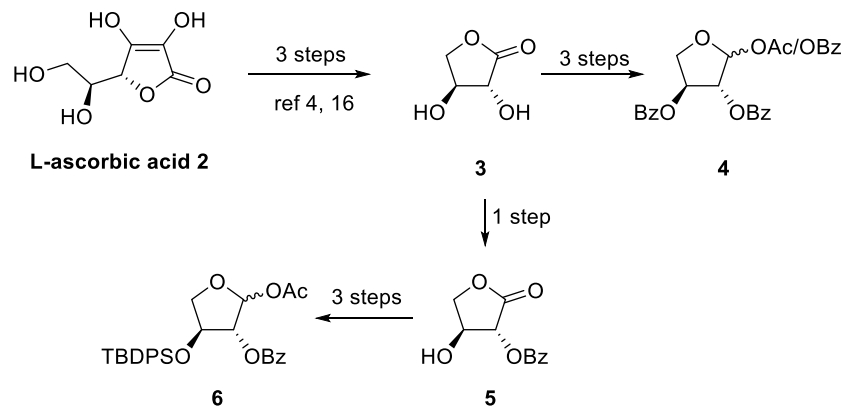

A variation of this regioselective reaction was also employed by the Chaput group for the synthesis of threose nucleic acid monomers. ${ }^{18}$

In this study, we developed additional synthetic approaches toward methyl L-threoside 9 as a convenient key intermediate for subsequent glycosylation reactions (Scheme 2). First, we

Scheme 2. Synthesis of 1-O-Methyl-L-threofuranose 9 from L-arabitol 7 and L-diethyl Tartrate $10^{a}$

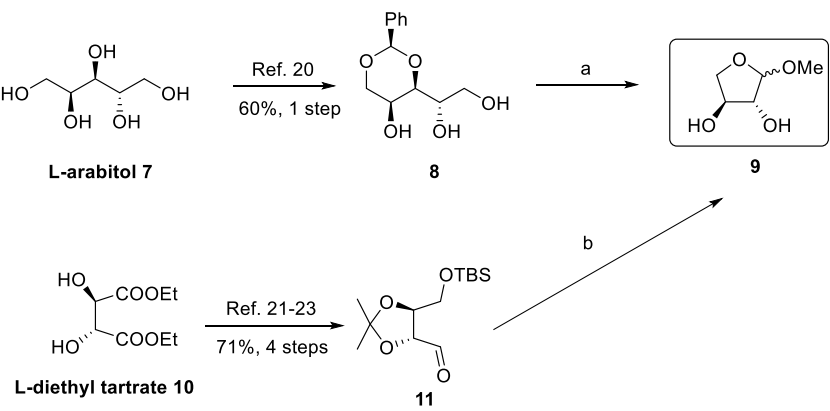

${ }^{a}$ Reagents and conditions: (a) (i) $\mathrm{NaIO}_{4}$, aq $\mathrm{MeOH}, 1 \mathrm{~h}, 0{ }^{\circ} \mathrm{C}$ and (ii) $1.25 \mathrm{M} \mathrm{HCl} / \mathrm{MeOH}, \mathrm{rt}, 12 \mathrm{~h}, 62 \%$ over 2 steps and (b) $1.25 \mathrm{M}$ $\mathrm{HCl} / \mathrm{MeOH}, \mathrm{rt}, 12 \mathrm{~h}, 50 \%$.

revisited the synthetic route from $\mathrm{L}$-arabitol 7 , which has been used previously as the starting material for the synthesis of the four-carbon L-threose sugar ${ }^{20}$ as well as an adenine containing L-threose nucleoside. ${ }^{11}$ Treatment of L-arabitol 7 with benzaldehyde in the presence of $\mathrm{HCl}$ gas yielded a mixture of isomers, from which enantiomerically pure 1,3-Obenzylidene arabitol 8 could be isolated upon recrystallization from 2-propanol in $60 \%$ yield and $>95 \%$ optical purity. ${ }^{21}$ Oxidative cleavage of the diol moiety of compound 8 with sodium periodate was followed by deprotection of the benzylidene moiety under acidic conditions, which occurred with concomitant cyclization, thus leading to the desired compound 9 in a $62 \%$ yield over two steps. The three-step route proceeded in an overall $37 \%$ yield and was reproducible on a multigram scale. Alternatively, compound 9 was accessible starting from L-diethyl tartrate 10, which was converted into aldehyde 11 following a reported method. ${ }^{22-24}$ Simultaneous removal of the tert-butyldimethylsilyl (TBS) and isopropylidene-protecting groups by treatment with $1.25 \mathrm{M} \mathrm{HCl} / \mathrm{MeOH}$ led to the formation of methyl threoside 9 in 35\% yield over five steps. Such a synthetic sequence can also be easily performed on a large scale.

Subsequent efforts were directed toward the synthesis of Lthreose nucleoside $\mathbf{1 7}$, as illustrated in Scheme 3. The regioselective benzoylation of L-threonolactone 3 to the corresponding 2-O-benzoyl analogue has been described previously. ${ }^{18,19}$ However, when similar reaction conditions were applied to achieve the protection of the 2-hydroxyl group of 1-O-methyl-L-threose 9, a mixture of regioisomers was formed instead along with 2,3-di-O-benzoylated product 12 . Therefore, we decided to continue our synthesis with dibenzoylated compound 12, which was first prepared in $85 \%$ yield from 9 and then converted to 1 -O-acetyl-2,3-Odibenzoyl-L-threofuranose 13. This intermediate served as the glycosyl donor in a Vorbrüggen reaction with $N^{6}$-benzoyladenine in the presence of trimethylsilyl trifluoromethanesulfonate (TMSOTf), furnishing benzoyl-protected L-threose nucleoside 14 in $77 \%$ yield. The regioselective cleavage of the $2^{\prime}-O$ - 
Scheme 3. Synthesis of $2^{\prime}$-Deoxy- $\alpha$-L-threofuranosyl Nucleoside $17^{a}$

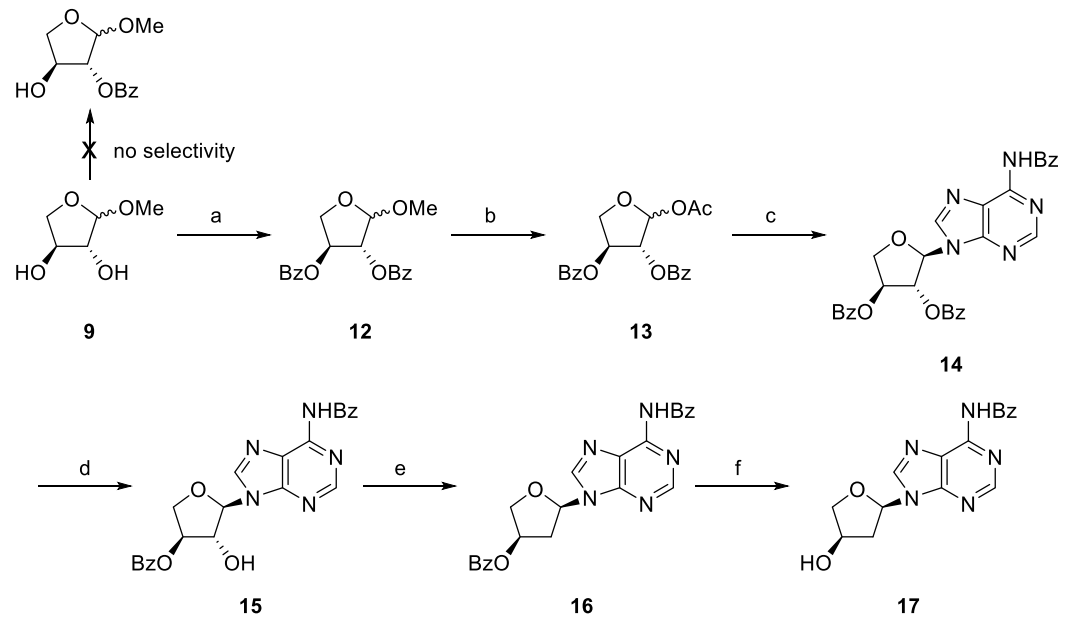

${ }^{a}$ Reagents and conditions: (a) BzCl, Pyr, $0{ }^{\circ} \mathrm{C}$ to rt, $12 \mathrm{~h}, 85 \%$; (b) acetic anhydride, $\mathrm{H}_{2} \mathrm{SO}_{4}, \mathrm{CH}_{2} \mathrm{Cl}_{2}, 0{ }^{\circ} \mathrm{C}$ to rt, $5 \mathrm{~h}, 80 \%$; (c) $N^{6}$-benzoyladenine, BSA, TMSOTf, toluene, $2.5 \mathrm{~h}, 95{ }^{\circ} \mathrm{C}, 77 \%$; (d) $\mathrm{KO}^{t} \mathrm{Bu}$, THF, $0{ }^{\circ} \mathrm{C}, 5 \mathrm{~min}, 81 \%$; (e) (i) TCDI, DMAP, $\mathrm{CH}_{2} \mathrm{Cl}_{2}, \mathrm{rt}, 12 \mathrm{~h},(\mathrm{ii}) \mathrm{Bu}_{3} \mathrm{SnH}, \mathrm{AIBN}$, toluene, reflux, $30 \mathrm{~min}, 80 \%$ over 2 steps; and (f) $1 \mathrm{~N} \mathrm{NaOH}, \mathrm{THF} / \mathrm{MeOH} / \mathrm{H}_{2} \mathrm{O}, 0{ }^{\circ} \mathrm{C}, 2 \mathrm{~h}, 71 \%$.

\section{Scheme 4. Synthesis of Phosphonomethoxydeoxythreosyl Adenine Prodrug $1^{a}$}

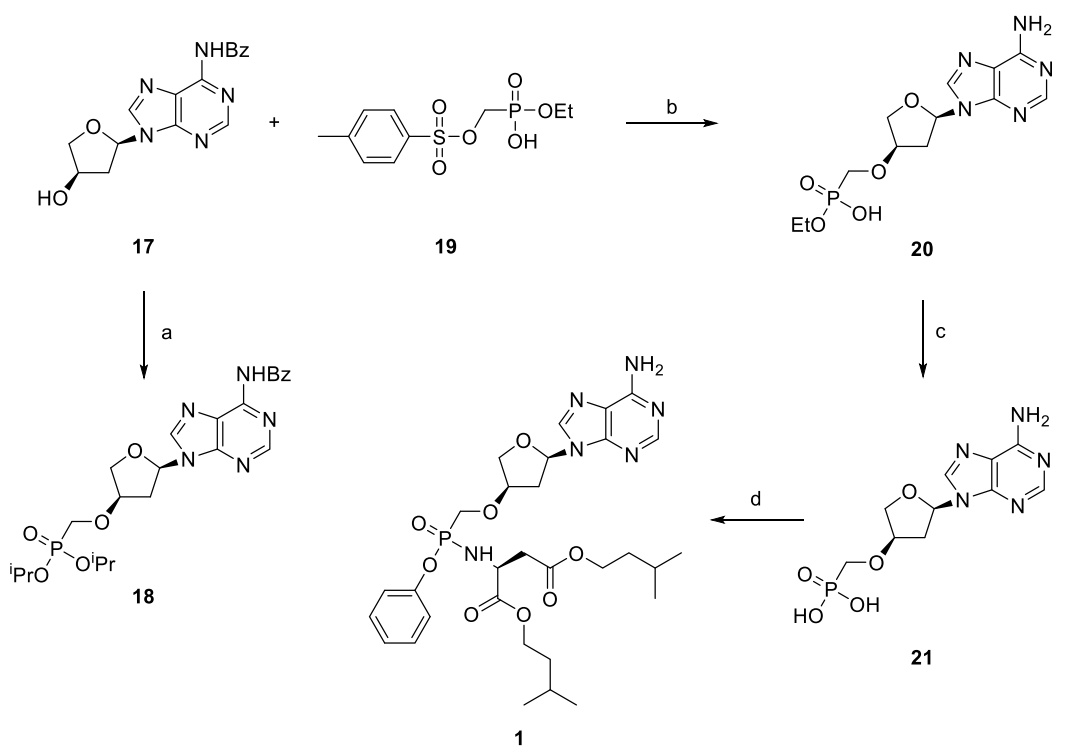

${ }^{a}$ Reagents and conditions: (a) diisopropylphosphonomethyl tosylate, NaH, DMF, $0{ }^{\circ} \mathrm{C}$ to rt, $12 \mathrm{~h}$; (b) (i) NaH, DMF, $0{ }^{\circ} \mathrm{C}$ to rt, 12 h; (ii) $\mathrm{NH}_{3} /$ $\mathrm{MeOH}, \mathrm{rt}, 12 \mathrm{~h}, 80 \%$ over 2 steps; (c) TMSBr, 2,6-lutidine, $\mathrm{CH}_{3} \mathrm{CN}, 0{ }^{\circ} \mathrm{C}$ to rt, $12 \mathrm{~h}, 70 \%$; and (d) L-aspartic acid isoamyl ester $\mathrm{HCl}, \mathrm{PhOH}, 2,2^{\prime}-$ dithiodipyridine, $\mathrm{PPh}_{3}, \mathrm{Et}_{3} \mathrm{~N}, \mathrm{Pyr}, 60{ }^{\circ} \mathrm{C}, 12 \mathrm{~h}, 66 \%$.

benzoyl group of $2^{\prime}, 3^{\prime}$-di-O-benzoyl threose nucleoside 14 with $0.5 \mathrm{M} \mathrm{KO}{ }^{t} \mathrm{Bu}$ in tetrahydrofuran (THF) at $0{ }^{\circ} \mathrm{C}$ successfully led to $3^{\prime}$-O-benzoyl threose nucleoside $\mathbf{1 5}$, in complete agreement with the literature data. ${ }^{25}$

Reductive removal of the $2^{\prime}$-hydroxyl group under standard Barton-McCombie deoxygenation conditions gave nucleoside 16. Finally, removal of the $3^{\prime}$-O-benzoyl group under alkaline conditions furnished L-2'-deoxythreose nucleoside 17 .

The most convenient method to introduce a phosphonomethoxy functionality on the sugar moiety of threose nucleosides is a phosphonylation reaction in the presence of diisopropylphosphonomethyl triflate and a strong base (e.g., $\mathrm{NaH}$ or BuLi). ${ }^{9}$ However, treatment of compound 17 under these reaction conditions resulted exclusively in the formation of undesired side products. The use of diisopropylphosphonomethyl tosylate in place of diisopropylphosphonomethyl triflate led only to a partial conversion of compound 17 to $\mathbf{1 8}$, resulting in a difficult chromatographic separation and unsatisfactory yield. Therefore, we decided to use a less sterically crowded monoester reagent, and for this purpose, we selected ( $p$-toluenesulfonyloxymethyl)phosphonic acid monoethyl ester 19, which was synthesized from the corresponding diethyl ester by alkaline hydrolysis. The introduction of the phosphonate group proceeded efficiently, followed by debenzoylation to give compound $\mathbf{2 0}$ in $80 \%$ yield over two steps (Scheme 4). Lewis-acid-assisted removal of the monoethyl ester using trimethylsilylbromide afforded L-2'deoxythreose nucleoside phosphonate 21. Finally, the free phosphonic acid $\mathbf{2 1}$ was converted to the corresponding aryloxy phosphonoamidate prodrug 1 using an established protocol. ${ }^{10}$ Protide $\mathbf{1}$ was isolated as a mixture of diastereomers 
and this mixture was used for all subsequent biological evaluations.

In Vitro Evaluation against an Entecavir-Resistant HBV Strain. As abovementioned, prodrug 1 was previously tested for its ability to inhibit the replication of HBV in the human hepatoblastoma HepG2 2.2.15 subclone cell line and reported to cause a reduction of both extracellular and intracellular HBV DNA copy numbers with low nanomolar potency. ${ }^{10}$ To further evaluate the anti-HBV activity, compound 1 was retested in HepG2 cells using wild-type and ETV-resistant HBV. To this end, HepG2 cells were infected with adenoviruses AdH294-WT and AdH294-7LR harboring wild-type HBV and ETV-resistant genomes (Figure 2A), respectively, followed by treatment with $\mathbf{1}$ for 5 days.

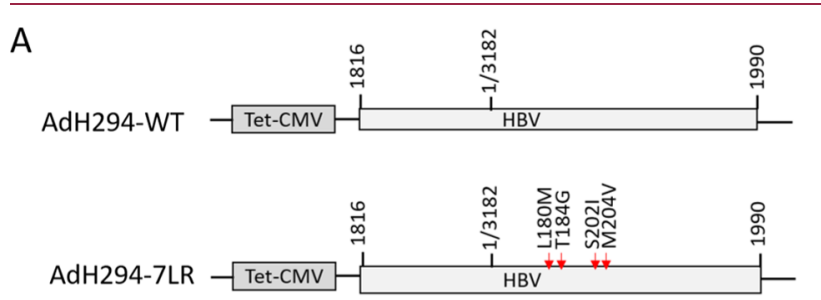

B

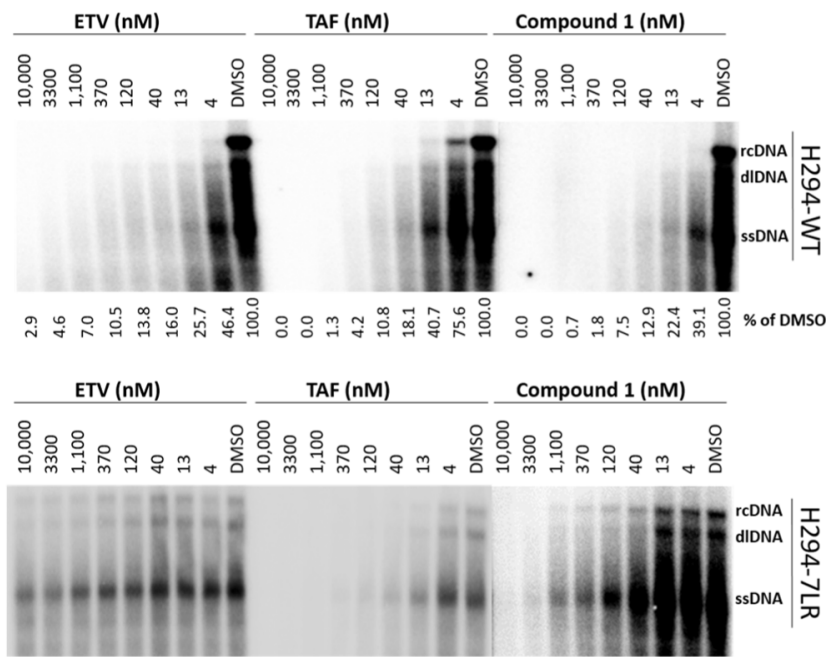

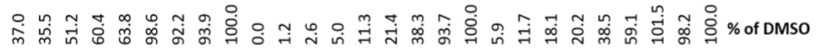

Figure 2. Inhibition of the replication of both HBV wild-type and ETV-resistant viruses in the presence of prodrug 1. (A) Diagrams of adenoviruses AdH294-WT and AdH294-7LR. ETV-resistant strain AdH294-7LR was generated by mutagenesis of four amino acids in the HBV reverse transcriptase region (red arrows). (B) Adenovirusinfected HepG2 cells were treated with serially diluted ETV, TAF, and prodrug 1 for 5 days. HBV replicative intermediate DNAs were extracted and detected with Southern blot using a P32-labeled HBV probe. The radioactive signal beneath each lane was quantified with Image software proportioned to DMSO treatment.

When the assay was conducted using wild-type HBV in the presence of compound $\mathbf{1}$, the levels of viral replicative intermediates in the cell were significantly suppressed. In particular, the $\mathrm{EC}_{50}$ of 1 was found to be lower than $4 \mathrm{nM}$, suggesting a potency comparable to that of ETV, while surpassing that of TAF (Figure 2B, upper panel). As expected, in HepG2 cells containing the ETV-resistant mutant, entecavir was unable to block the viral replication even at high concentrations up to $10 \mu \mathrm{M}$. In contrast, both 1 and TAF were able to reduce the viral DNA levels significantly at submicromolar concentrations. In the case of the ETVresistant virus, prodrug 1 seemed to be less effective than TAF (Figure 2B, lower panel).

Effect on HBV cccDNA in a Cell-Based Assay. HBV persists in the nucleus of the infected cells in the form of cccDNA. cccDNA is thought to play a crucial role in the persistence and replication of $\mathrm{HBV}^{26,27}$ Elimination of the HBV cccDNA from infected cells is thought to be important as a HBV cure strategy. ${ }^{27}$ To evaluate the effect of compound 1 on the HBV cccDNA levels in the cells, a cell-based assay using HepDE19 cells was used. ${ }^{28}$ HepDE19 cells can be induced to allow HBV replication and produce cccDNA in response to tetracycline withdrawal (doxycycline in the experiments described here). HBV cccDNA synthesis was induced in HepDE-19 cells (doxycycline withdrawal) in the presence of various concentrations of $\mathbf{1}$ (6-point titration in triplicates ranging from $1 \mu \mathrm{M}$ to $\left.1 \times 10^{-5} \mu \mathrm{M}\right)$. TAF was used as a positive control in the assay. $\mathrm{HBV}$ cccDNA levels were measured at the end of 9 days after T5 exonuclease digestion using HBV cccDNA specific quantitative PCR (qPCR). Beta actin ( $\beta$-actin) DNA levels before T5 exonuclease treatment were measured by qPCR to evaluate the compound cytotoxicity. Although currently available nucleoside analogues are not shown to target cccDNA, it is worth noting that most of the published literature for cccDNA activity for nucleoside analogues is based upon Southern blotting, which is less sensitive (requiring $10^{5}$ to $10^{6}$ copies/gel lane). The assay system used in the current study is based upon a more sensitive HBV cccDNA detection system (cccDNA-specific qPCR, sensitivity up to 100 copies/reaction) in the inducible HepDE19 cccDNA assay system. As shown in Table 1,

Table 1. Activity of Prodrug 1 in a HBV cccDNA Assay

$\begin{array}{lcccc}\text { compound } & \mathrm{IC}_{50}(\mu \mathrm{M})^{a} & \mathrm{CC}_{50}(\mu \mathrm{M})^{b} & \mathrm{IC}_{90}(\mu \mathrm{M}) & \mathrm{SI}=\mathrm{CC}_{50} / \mathrm{IC}_{50} \\ \mathbf{1} & 0.006 & 0.23 & 0.07 & 37 \\ \mathrm{TAF}^{c} & 0.04 & 0.50 & >0.1 & 13\end{array}$

${ }^{a}$ Antiviral activity against HBV cccDNA measured by cccDNAspecific qPCR in HepDE19 cells. ${ }^{b}$ Cytotoxicity measured by $\beta$-actin qPCR. ${ }^{c}$ Positive control.

compound $\mathbf{1}$ exhibited profound activity in reducing $\mathrm{HBV}$ cccDNA in this assay, with an $\mathrm{EC}_{50}$ of $0.006 \mu \mathrm{M}$ and a selectivity index of 37 . Notably, compound 1 was more effective in reducing $\mathrm{HBV}$ cccDNA compared to the positive control TAF ( $\mathrm{EC}_{50}$ of $0.04 \mu \mathrm{M}$ and selectivity index of 13) (Table 1).

In Vivo Plasma Pharmacokinetic Study. In order to determine its plasma pharmacokinetics, compound $\mathbf{1}$ was administered to mice via a single oral dose of $6 \mathrm{mg} / \mathrm{kg}$ and plasma samples were taken at different time points after administration $(0.25,0.5,1,2,4,6,8,12$, and $24 \mathrm{~h}$ after dosing). The plasma concentrations of compound 1 were not quantifiable (with a lower limit of quantification of $1.01 \mathrm{ng} /$ $\mathrm{mL}$ ) across these time points. Similarly, the parent phosphonate $\mathbf{2 1}$ was also undetectable in these different plasma samples. Previously, we demonstrated that $\mathbf{1}$ is highly metabolically unstable in the presence of liver S9 fraction and liver microsomes with a half-life of approximately $10 \mathrm{~min}^{10}$ We, therefore, speculated that, upon oral administration of compound 1, first-pass metabolism will quickly generate high 
levels of nucleoside phosphonate $\mathbf{2 1}$ (which is the biologically active species after its intracellular conversion to the diphospho metabolite) in hepatocytes, ultimately resulting in high drug exposure in the liver, making it a promising drug candidate for the treatment of HBV infection. The absence of detectable levels of prodrug $\mathbf{1}$ and phosphonate $\mathbf{2 1}$ in plasma strongly suggests that these compounds accumulate in the liver. This tissue targeted drug delivery and lack of systemic exposure is especially advantageous for treating a liver disease such as the HBV infection.

In Vivo Anti-HBV Study. Compound 1 was investigated for its in vivo efficacy against $\mathrm{HBV}$ infection in a hydrodynamic injection (HDI) mouse model. An HBV 1.3 mer plasmid was injected hydrodynamically to produce $\mathrm{HBV}$ replication in hepatocytes. One day later, the mice were treated with either ETV (at a dose of $0.1 \mathrm{mg} / \mathrm{kg} /$ day) or TAF (at doses of $0.6,6$ and $60 \mathrm{mg} / \mathrm{kg} /$ day) as positive controls. Similar to TAF, compound 1 was given orally at three different doses $(0.6,6$, and $60 \mathrm{mg} / \mathrm{kg} /$ day $)$. During the whole time of treatment, no body weight change was observed (Figure S1, Supporting Information). Blood samples were collected at four different time points and serum HBV DNA was measured by qPCR. In comparison to the vehicle control at each time point after treatment, a clear dose-dependent reduction in HBV DNA copy numbers was observed for both positive controls ETV and TAF (Figure 3). After 2 days, TAF and compound 1

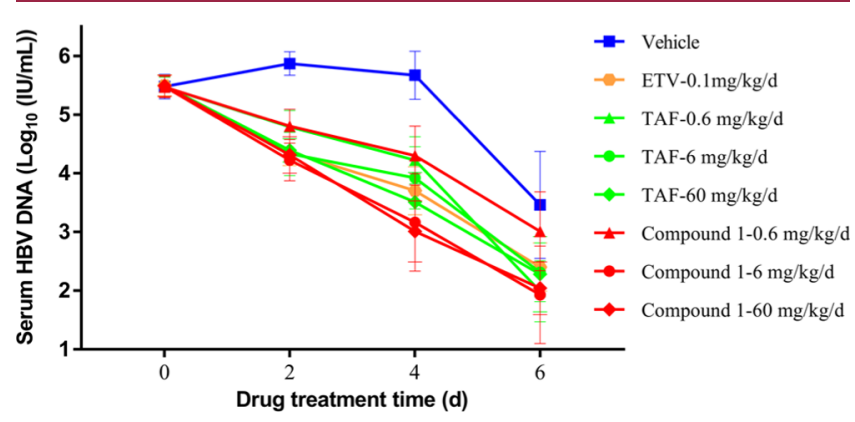

Figure 3. Antiviral activity of compound $\mathbf{1}$ in a HBV hydrodynamic mouse model. One day after hydrodynamic injection of HBV $1.3 \mathrm{mer}$ plasmid (day 0), six-week-old male C57BL/6 mice were treated with TAF or compound 1 at doses of $0.6,6$, and $60 \mathrm{mg} / \mathrm{kg}$ or the vehicle via oral gavage once daily. ETV, which serves as positive control, was also administered orally once daily at a single dose of $0.1 \mathrm{mg} / \mathrm{kg}$. Ten mice were included in each group. Blood was collected at $0.2,4$, and 6 days post-treatment and serum HBV DNA was extracted and analyzed by a real-time PCR assay. Mean values \pm SD are plotted for each group.

performed similarly. After 4 and 6 days, compound 1 performed somewhat better than TAF except at the lowest concentration of $0.6 \mathrm{mg} / \mathrm{kg} /$ day (Figures S2-S4, Supporting Information). Altogether, these data demonstrate that the oral administration of compound $\mathbf{1}$ resulted in potent anti-HBV activity.

In Vivo Toxicity Study. As no signs of toxicity were observed when compound $\mathbf{1}$ was evaluated in the HDI mouse model, a repeated dose toxicity study in mice was performed. Compound 1 was orally administered once daily at a dose of $60 \mathrm{mg} / \mathrm{kg}$ during 14 consecutive days. During the treatment, no animals died, and the clinical observations did not reveal any signs of functional deficits in male or female mice. A loss of body weight (4\%) and decreased food consumption in male mice relative to those of the controls were only observed after
11 days. Hematology evaluation showed that the number of neutrophils increased, whereas the number of erythrocytes, hemoglobin, hematocrit, mean corpuscular volume, and lymphocytes decreased in male mice but not in female mice. Clinical chemistry results were statistically comparable to control animals of both sexes, except for increases in the lowdensity lipoprotein cholesterol concentration in males. Organ weights of all treated animals were comparable to those of control animals of both sexes, except for increased thymus weights observed in females.

Ames Test. Compound 1 was tested at $1 \mu \mathrm{M}$ in an Ames test and no mutagenic effect was observed. In particular, the number of colonies of auxotrophic Salmonella typhimurium strains (TA98, TA100, TA1535, TA1537, and TA1537) did not significantly increase in the presence of compound $\mathbf{1}$ as compared with the spontaneous revertants counted when the experiment was conducted without adding the compound.

\section{CONCLUSIONS}

In summary, the synthesis of a protected L-threofuranose sugar synthon is described starting from either L-arabitol or L-diethyl tartrate as an alternative to the commonly used route from Lascorbic acid. This L-threose intermediate was employed as a glycosyl donor for the large-scale preparation of the aryloxy phosphonoamidate prodrug 1 that was previously shown to be a very potent inhibitor of $\mathrm{HBV}$ replication in vitro. In this study, it was shown that compound $\mathbf{1}$ displayed potent in vitro antiviral activity against ETV-resistant $\mathrm{HBV}$ and caused a significant reduction of $\mathrm{HBV}$ cccDNA in a cellular assay. Furthermore, the easy access to larger amounts of compound $\mathbf{1}$ allowed us to demonstrate an in vivo antiviral efficacy of prodrug 1 comparable to TAF. In addition, a 14 day toxicity study did not reveal any signs of toxicity and an in vivo pharmacokinetic study strongly suggested that prodrug 1 was predominantly metabolized in the liver. Overall, these data suggest that prodrugs of PDMTA are promising lead compounds for anti-HBV drug discovery.

\section{EXPERIMENTAL SECTION}

Chemistry. ${ }^{1} \mathrm{H},{ }^{13} \mathrm{C}$, and ${ }^{31} \mathrm{P}$ NMR spectra were recorded with a 300 , 500, or $600 \mathrm{MHz}$ Bruker AVANCE spectrometer using tetramethylsilane or the residual solvent signal as the internal standard. 2D NMR (H-COSY, HSQC, and HMBC) spectroscopic techniques were used for the assignment of the proton and carbon signals of intermediates and final compounds. All reagents and solvents were purchased from commercial sources and used as received without further purification. All moisture-sensitive reactions were performed in oven-dried glassware under a nitrogen or argon atmosphere. High-resolution mass spectra (HRMS) were obtained on a quadruple orthogonal acceleration time-of-flight mass spectrometer (Synapt G2 HDMS, Waters, Milford, MA). Samples were infused at 3 $\mu \mathrm{L} / \mathrm{min}$, and spectra were obtained in a positive (or negative) ionization mode with a resolution of 15000 FWHM using leucine enkephalin as lock mass. Column chromatography was performed using silica gel $60 \AA ̊, 0.035-0.070 \mathrm{~mm}$ (Acros Organics). Precoated aluminum sheets (silica gel matrix, $254 \mathrm{~nm}$ ) were used for thin layer chromatography. The purity of compound 1 was determined to be $>$ $95 \%$ by analytical HPLC analysis. The following HPLC equipment and conditions were employed: Shimadzu HPLC equipped with a LC-20AT pump, a DGU20A5 degasser, and a SPD-20A UV detector; Inertsil ODS-3 $(4 \mu \mathrm{m}, 4.6 \mathrm{~mm} \times 100 \mathrm{~mm})$ or Symmetry C18 column $\left(5 \mu \mathrm{m}, 4.6 \mathrm{~mm} \times 150 \mathrm{~mm}\right.$ ); gradient elution of $\mathrm{H}_{2} \mathrm{O} / \mathrm{CH}_{3} \mathrm{CN}$ from $95 / 5$ to $5 / 95$ in $15 \mathrm{~min}$; flow rate, $1 \mathrm{~mL} / \mathrm{min}$; and UV wavelength, $254 \mathrm{~nm}$. 
(3R,4S)-2-Methoxytetrahydrofuran-3,4-diol (9). Method A. An aqueous solution of $\mathrm{NaIO}_{4}(41.8 \mathrm{~g}, 196 \mathrm{mmol})$ in water $(100 \mathrm{~mL})$ was added dropwise to a solution of compound $8^{21}(47 \mathrm{~g}, 196 \mathrm{mmol})$ in methanol $(250 \mathrm{~mL})$ at $0{ }^{\circ} \mathrm{C}$ over $10 \mathrm{~min}$. The resulting mixture was stirred for $1 \mathrm{~h}$. The white solid was filtered off, and the filtrate was concentrated affording a crude residue that was redissolved in ethyl acetate $(200 \mathrm{~mL})$. This solution was washed with brine $(100 \mathrm{~mL})$. The organic layer was separated, dried over $\mathrm{Na}_{2} \mathrm{SO}_{4}$, filtered, and concentrated in vacuo to afford crude 2,4-O-benzylidene-L-threose as a white foam that was used in the next step without further purification. The crude 2,4-O-benzylidene-L-threose was dissolved in a $1.25 \mathrm{M}$ methanolic $\mathrm{HCl}$ solution $(200 \mathrm{~mL})$, which was stirred at room temperature for $12 \mathrm{~h}$. The reaction mixture was quenched with solid $\mathrm{NaHCO}_{3}$ and filtered. The filtrate was evaporated to give a crude residue, which was purified by silica gel chromatography (gradient $\mathrm{DCM} / \mathrm{MeOH}, 25: 1, \mathrm{v} / \mathrm{v} ; 20: 1, \mathrm{v} / \mathrm{v} ; 15: 1, \mathrm{v} / \mathrm{v}$ ) to afford compound 9 as a colorless oil (16.3 g, 62\% over two steps). Compound 9 was isolated as an anomeric mixture, consisting of diastereoisomers $9 \alpha$ and $9 \beta$. At this stage, the assignment of compound $9 \alpha$ or $9 \boldsymbol{\beta}$ was not performed, and their mixture was used as such in the next step. ${ }^{1} \mathrm{H}$ NMR $\left(600 \mathrm{MHz}, \mathrm{CD}_{3} \mathrm{OD}\right): \delta 4.83-4.82(\mathrm{~m}, \mathrm{H}-1, \alpha$ or $\beta), 4.75-4.74$ (m, H-1, $\alpha$ or $\beta$ ), 4.19-4.15 (m, H-3, H-4, $\alpha$ or $\beta$ ), 4.09-4.05 (m, H$4, \mathrm{H}-3, \alpha$ or $\beta)$, 3.94-3.92 (m, H-2, $\alpha+\beta), 3.73(\mathrm{dd}, J=9.3,4.6 \mathrm{~Hz}$, $\mathrm{H}-4, \alpha$ or $\beta), 3.57(\mathrm{dd}, J=9.2,4.3 \mathrm{~Hz}, \mathrm{H}-4, \alpha$ or $\beta), 3.40\left(\mathrm{~s}, \mathrm{OCH}_{3} \alpha\right.$ or $\beta), 3.34\left(\mathrm{~s}, \mathrm{OCH}_{3} \alpha\right.$ or $\left.\beta\right) ;{ }^{13} \mathrm{C}$ NMR $\left(125 \mathrm{MHz}, \mathrm{CD}_{3} \mathrm{OD}\right): \delta$ 111.0, 104.7 (C-1), 82.7, 79.5 (C-2), 77.8, 76.5 (C-3), 74.1, 72.2 (C4), 55.7, $55.2\left(\mathrm{OCH}_{3}\right)$.

Method B. A solution of compound $11^{22-24}(1.0 \mathrm{~g}, 3.64 \mathrm{mmol})$ in $1.25 \mathrm{M}$ methanolic $\mathrm{HCl}(100 \mathrm{~mL})$ was stirred at room temperature for $12 \mathrm{~h}$. The reaction mixture was quenched with solid $\mathrm{NaHCO}_{3}$ and filtered. The filtrate was evaporated to give a crude residue, which was purified by silica gel chromatography (gradient $\mathrm{DCM} / \mathrm{MeOH}, 25: 1$, $\mathrm{v} / \mathrm{v} ; 20: 1, \mathrm{v} / \mathrm{v} ; 15: 1, \mathrm{v} / \mathrm{v})$ to afford compound $9(244 \mathrm{mg}, 50 \%)$, as a mixture of anomers $9 \alpha$ and $9 \boldsymbol{\beta}$.

1-O-Methyl-2,3-di-O-benzoyl-L-threose (12). To a solution of compound $9(16.0 \mathrm{~g}, 12 \mathrm{mmol})$ in dry pyridine $(200 \mathrm{~mL})$ was added $\mathrm{BzCl}(48.0 \mathrm{~mL}, 42.0 \mathrm{mmol})$ dropwise at $0{ }^{\circ} \mathrm{C}$. The reaction mixture was warmed to room temperature and stirred for $12 \mathrm{~h}$. It was then evaporated to give a crude residue that was redissolved in DCM (300 $\mathrm{mL})$. This solution was washed with saturated aq $\mathrm{NaHCO}_{3}(200 \mathrm{~mL})$ and brine $(100 \mathrm{~mL})$. The organic layer was separated, dried over $\mathrm{Na}_{2} \mathrm{SO}_{4}$, filtered, and concentrated under reduced pressure. The crude residue was purified by silica gel chromatography (gradient hexane/ ethyl acetate, $30: 1, \mathrm{v} / \mathrm{v} ; 20: 1, \mathrm{v} / \mathrm{v}$ ) to afford compound 12 as a colorless oil (37.5 g, 85\%) consisting of two diastereoisomers $12 \alpha$ and $12 \beta$. At this stage, $12 \alpha$ or $12 \beta$ was not separated, and their mixture was used as such in the next step. ${ }^{1} \mathrm{H}$ NMR $\left(300 \mathrm{MHz}, \mathrm{CDCl}_{3}\right): \delta$ 8.11-8.04 (m, ArH), 7.57-7.39 (m, ArH), 5.79-5.75 (m, H-1, $\alpha$ or $\beta), 5.55-5.36(\mathrm{~m}, \mathrm{H}-1, \mathrm{H}-2, \mathrm{H}-3, \alpha$ or $\beta), 5.11$ (s, H-3, $\alpha$ or $\beta), 4.64$ (dd, $J=10.0,6.8 \mathrm{~Hz}, \mathrm{H}-4, \alpha$ or $\beta$ ), 4.48 (dd, $J=10.5,6.6 \mathrm{~Hz}, \mathrm{H}-4, \alpha$ or $\beta), 4.02(\mathrm{dd}, J=10.0,5.1 \mathrm{~Hz}, \mathrm{H}-4, \alpha$ or $\beta), 3.94(\mathrm{dd}, J=10.5,3.3$ $\mathrm{Hz}, \mathrm{H}-4, \alpha$ or $\beta), 3.45\left(\mathrm{~s}, \mathrm{OCH}_{3}, \alpha\right.$ or $\left.\beta\right), 3.38\left(\mathrm{~s}, \mathrm{OCH}_{3}, \alpha\right.$ or $\left.\beta\right) ;{ }^{13} \mathrm{C}$ $\left.\operatorname{NMR}\left(75 \mathrm{MHz}^{\mathrm{CDCl}}\right)_{3}\right): \delta 166.6,166.2,165.7(\mathrm{COPh}), 138.3,133.7$, 130.2, 130.1, 129.6, 129.5, 128.8, 128.7 (Ar-C), 107.1, 101.6 (C-1), 81.9, 78.6 (C-2), 77.3, 77.1 (C-3), 71.4, 69.4 (C-4), 55.6, 55.1 $\left(\mathrm{OCH}_{3}\right)$; HRMS for $\mathrm{C}_{19} \mathrm{H}_{18} \mathrm{O}_{6} \mathrm{Na}[\mathrm{M}+\mathrm{Na}]^{+}$calcd, 365.0996; found, 365.0994 .

1-O-Acetyl-2,3-di-O-benzoyl-L-threose (13). ${ }^{17}$ To a solution of compound $12(12.0 \mathrm{~g}, 34.8 \mathrm{mmol})$ in anhydrous DCM $(200 \mathrm{~mL})$ was added acetic anhydride $(13.2 \mathrm{~mL}, 140.0 \mathrm{mmol})$ and a catalytic amount of sulfuric acid (10 drops) at $0{ }^{\circ} \mathrm{C}$. After stirring at room temperature for $5 \mathrm{~h}$, the reaction mixture was neutralized by addition of $\mathrm{Et}_{3} \mathrm{~N}$ at $0{ }^{\circ} \mathrm{C}$ and concentrated under reduced pressure. The crude product was dissolved in EtOAc $(200 \mathrm{~mL})$, washed with brine, dried over $\mathrm{Na}_{2} \mathrm{SO}_{4}$, filtered, and concentrated under reduced pressure. The residue was purified by silica gel chromatography (gradient hexane/ ethyl acetate, 15:1, v/v; 10:1, v/v; 7:1, v/v) to afford compound 13 as a colorless oil $(10.4 \mathrm{~g}, 80 \%)$. Compound 13 consisted of a mixture of two diastereoisomers $13 \alpha$ and $13 \beta$. At this stage, $13 \alpha$ or $13 \beta$ was not separated, and their mixture was used as such in the next step. ${ }^{1} \mathrm{H}$
NMR $\left(300 \mathrm{MHz}, \mathrm{CDCl}_{3}\right): \delta 8.10-8.02(\mathrm{~m}, \mathrm{ArH}), 7.61-7.39(\mathrm{~m}$, $\mathrm{ArH}), 6.65(\mathrm{~d}, J=4.5 \mathrm{~Hz}, \mathrm{H}-1, \alpha$ or $\beta), 6.39(\mathrm{~s}, \mathrm{H}-1, \alpha$ or $\beta), 5.76-$ $5.68(\mathrm{~m}, \mathrm{H}-3, \mathrm{H}-2, \alpha$ or $\beta), 5.64$ (s, H-2, $\alpha$ or $\beta), 5.58-5.55(\mathrm{~m}, \mathrm{H}-3$, $\alpha$ or $\beta$ ), 4.65 (dd, $J=10.5,6.0 \mathrm{~Hz}, \mathrm{H}-4, \alpha$ or $\beta$ ), 4.61-4.57 (m, H-4, $\alpha$ or $\beta$ ), 4.21 (ddd, $J=10.5,3.7,1.2 \mathrm{~Hz}, \mathrm{H}-4, \alpha$ or $\beta$ ), 4.04 (dd, $J=10.6$, $3.4 \mathrm{~Hz}, \mathrm{H}-4, \alpha$ or $\beta), 2.13\left(\mathrm{OCH}_{3}, \alpha\right.$ or $\left.\beta\right), 2.01\left(\mathrm{OCH}_{3}, \alpha\right.$ or $\left.\beta\right) ;{ }^{1} \mathrm{H}$ $\operatorname{NMR}\left(75 \mathrm{MHz}, \mathrm{CDCl}_{3}\right): \delta 169.2,166.0,165.5,165.3,165.0(\mathrm{COPh}$, $\mathrm{COMe}), 133.6,133.5,129.9,129.8,128.5,128.4$ (Ar-C), 99.4, 94.3 (C-1), 80.4, 76.7 (C-2), 76.0 (C-3), 73.2, 70.9 (C-4), 20.9, 20.8 $\left(\mathrm{OCH}_{3}\right)$; HRMS for $\mathrm{C}_{20} \mathrm{H}_{18} \mathrm{O}_{7} \mathrm{Na}[\mathrm{M}+\mathrm{Na}]^{+}$calcd, 393.0945; found, 393.0949

$1^{\prime} \alpha$-(N'-Benzoyladenin-9-yl)-2', $3^{\prime}$-di-O-benzoyl-L-threose (14). ${ }^{17}$ A mixture of compound $13(8.5 \mathrm{~g}, 23.0 \mathrm{mmol})$ and $\mathrm{N}^{6}$ benzoyladenine $(5.5 \mathrm{~g}, 23.0 \mathrm{mmol}$ ) was coevaporated with anhydrous toluene $(100 \mathrm{~mL})$ and then suspended in anhydrous toluene $(200$ $\mathrm{mL}$ ). To this suspension was added N,O-bis(trimethylsilyl)acetamide $(11.2 \mathrm{~mL})$, and the mixture was stirred for $30 \mathrm{~min}$ at $95{ }^{\circ} \mathrm{C}$ until a clear solution was formed. Then, TMSOTf $(6.23 \mathrm{~mL})$ was added dropwise. After heating at $95{ }^{\circ} \mathrm{C}$ for $2 \mathrm{~h}$, the mixture was cooled to room temperature and poured into an ice-cold solution of saturated aq $\mathrm{NaHCO}_{3} / \mathrm{EtOAc}(300 \mathrm{~mL}, 1: 1)$. The organic layer was separated and the aqueous layer was extracted with EtOAc. The combined organic layers were washed with brine, dried over $\mathrm{Na}_{2} \mathrm{SO}_{4}$, filtered, and concentrated under reduced pressure. The crude residue was purified by silica gel chromatography (gradient hexane/ethyl acetate, $8: 1, \mathrm{v} / \mathrm{v} ; 7: 1, \mathrm{v} / \mathrm{v} ; 6: 1, \mathrm{v} / \mathrm{v})$ to afford compound $\mathbf{1 4}(10 \mathrm{~g}, 77 \%)$ as a white foam. ${ }^{1} \mathrm{H}$ NMR $\left(600 \mathrm{MHz}, \mathrm{CDCl}_{3}\right): \delta 9.05(\mathrm{~s}, 1 \mathrm{H}, \mathrm{NH}), 8.76$ $(\mathrm{s}, 1 \mathrm{H}, \mathrm{H}-2), 8.32(\mathrm{~s}, 1 \mathrm{H}, \mathrm{H}-8), 8.10-8.08(\mathrm{~m}, 2 \mathrm{H}, \mathrm{ArH}), 8.03-8.01$ (m, 2H, ArH), 7.88-7.86 (m, 2H, ArH), 7.65-7.43 (m, 9H, ArH), $6.46\left(\mathrm{~d}, J=2.0 \mathrm{~Hz}, 1 \mathrm{H}, \mathrm{H}-\mathrm{1}^{\prime}\right), 6.30\left(\mathrm{~d}, J=1.8 \mathrm{~Hz}, 1 \mathrm{H}, \mathrm{H}-2^{\prime}\right), 5.77-$ $5.76\left(\mathrm{~m}, 1 \mathrm{H}, \mathrm{H}-3^{\prime}\right), 4.67\left(\mathrm{dd}, J=11.0,4.8 \mathrm{~Hz}, 1 \mathrm{H}, \mathrm{H}-4^{\prime} \mathrm{a}\right), 4.56(\mathrm{dd}, J$ $\left.=11.0,2.2 \mathrm{~Hz}, 1 \mathrm{H}, \mathrm{H}-4^{\prime} \mathrm{b}\right)$; ${ }^{13} \mathrm{C}$ NMR $\left(125 \mathrm{MHz} \mathrm{CDCl}_{3}\right): \delta 165.5$, 165.1, 164.7 (COPh), 153.1 (C-2), 151.8 (C-4), 149.7 (C-6), 141.2 (C-8), 134.2, 134.0, 132.9, 130.2, 129.8, 129.0, 128.9, 128.6, 128.5, 128.0 (Ar-C), $123.5(\mathrm{C}-5), 89.2\left(\mathrm{C}-1^{\prime}\right), 80.2\left(\mathrm{C}-2^{\prime}\right), 76.6\left(\mathrm{C}-3^{\prime}\right)$, $73.7\left(\mathrm{C}-4^{\prime}\right)$; HRMS for $\mathrm{C}_{30} \mathrm{H}_{24} \mathrm{~N}_{5} \mathrm{O}_{6}[\mathrm{M}+\mathrm{H}]^{+}$calcd, 550.1721; found, 550.1733 .

$1^{\prime} \alpha$-(N6-Benzoyladenin-9-yl)-3'-O-benzoyl-L-threose (15). ${ }^{25}$ To a solution of compound $14(10.0 \mathrm{~g}, 18.2 \mathrm{mmol})$ in dry THF $(300 \mathrm{~mL})$ was added a freshly prepared $0.5 \mathrm{M} \mathrm{KO}^{t} \mathrm{Bu}$ solution in THF $(91 \mathrm{~mL}$, $45.5 \mathrm{mmol}$ ) dropwise at $0{ }^{\circ} \mathrm{C}$. After stirring for $5 \mathrm{~min}$, the mixture was quenched by addition of a $1 \mathrm{~N} \mathrm{HCl}$ solution $(45.5 \mathrm{~mL}, 45.5 \mathrm{mmol})$. The resulting solution was diluted with ethyl acetate $(250 \mathrm{~mL})$, washed with brine, dried over $\mathrm{Na}_{2} \mathrm{SO}_{4}$, filtered, and concentrated under reduced pressure to give a crude residue, which was recrystallized from ethanol to afford compound 15 as a white power $(6.5 \mathrm{~g}, 81 \%) .{ }^{1} \mathrm{H}$ NMR $\left(600 \mathrm{MHz}, \mathrm{CDCl}_{3}\right): \delta 9.03(\mathrm{~s}, 1 \mathrm{H}$, $\mathrm{NH}), 8.72(\mathrm{~s}, 1 \mathrm{H}, \mathrm{H}-8), 8.27(\mathrm{~s}, 1 \mathrm{H}, \mathrm{H}-2), 8.01(\mathrm{~d}, J=7.7 \mathrm{~Hz}, 2 \mathrm{H}$ $\mathrm{ArH}), 7.83(\mathrm{~d}, J=7.8 \mathrm{~Hz}, 2 \mathrm{H}, \mathrm{ArH}), 7.61(\mathrm{t}, J=7.3 \mathrm{~Hz}, 1 \mathrm{H}, \operatorname{ArH})$, 7.55-7.51 (m, 3H, ArH), 7.42-7.39 (m, 3H, ArH), $6.16(\mathrm{~d}, J=2.9$ $\left.\mathrm{Hz}, 1 \mathrm{H}, \mathrm{H}-1^{\prime}\right), 5.50-5.49\left(\mathrm{~m}, 1 \mathrm{H}, \mathrm{H}-3^{\prime}\right), 5.06(\mathrm{~d}, J=2.8 \mathrm{~Hz}, 1 \mathrm{H}, \mathrm{H}-$ $\left.2^{\prime}\right), 4.63\left(\mathrm{dd}, J=10.6,5.2 \mathrm{~Hz}, 1 \mathrm{H}, \mathrm{H}-4^{\prime} \mathrm{a}\right), 4.49(\mathrm{dd}, J=10.7,2.9 \mathrm{~Hz}$, $\left.1 \mathrm{H}, \mathrm{H}-4^{\prime} \mathrm{b}\right) ;{ }^{13} \mathrm{C} \mathrm{NMR}\left(125 \mathrm{MHz}, \mathrm{CDCl}_{3}\right): \delta 166.2,164.7(\mathrm{COPh})$, 152.7 (C-2), 151.3 (C-4), 149.7 (C-6), 141.2 (C-8), 133.9, 133.6, 133.1, 129.8 129.5, 129.1, 128.8, 128.0 (Ar-C), 123.5 (C-5), 91.7 (C$\left.1^{\prime}\right), 79.6\left(\mathrm{C}-3^{\prime}\right), 79.0\left(\mathrm{C}-2^{\prime}\right)$, $73.0\left(\mathrm{C}-4^{\prime}\right)$; HRMS for $\mathrm{C}_{23} \mathrm{H}_{20} \mathrm{~N}_{5} \mathrm{O}_{5}$ $[\mathrm{M}+\mathrm{H}]^{+}$calcd, 446.1459; found, 446.1456 .

$1^{\prime} \alpha$-( $N^{6}$-Benzoyladenin-9-yl)-2' -deoxy-3'-O-benzoyl-L-threose (16). To a solution of compound $15(6.5 \mathrm{~g}, 14.6 \mathrm{mmol})$ and DMAP $(550 \mathrm{mg}, 4.38 \mathrm{mmol})$ in anhydrous $\mathrm{CH}_{2} \mathrm{Cl}_{2}(300 \mathrm{~mL})$ was added $1,1^{\prime}$-thiocarbonyldiimidazole (TCDI) $(3.9 \mathrm{~g}, 21.9 \mathrm{mmol})$ at room temperature. The reaction mixture was stirred at room temperature for $12 \mathrm{~h}$. Then, the solution was washed with brine, dried over $\mathrm{Na}_{2} \mathrm{SO}_{4}$, filtered, and concentrated under reduced pressure to give a crude residue that was redissolved in toluene $(400 \mathrm{~mL})$. Azobis(isobutyronitrile) (AIBN) $(1.2 \mathrm{~g}, 7.30 \mathrm{mmol})$ and tributyltin hydride $(15.7 \mathrm{~mL}, 53.4 \mathrm{mmol})$ were then added, and the reaction mixture was refluxed for $30 \mathrm{~min}$. The solvent was removed under reduced pressure, and the residue was purified by silica gel chromatography (gradient DCM/acetone, $8: 1, \mathrm{v} / \mathrm{v} ; 7: 1, \mathrm{v} / \mathrm{v} ; 6: 1, \mathrm{v} / \mathrm{v} ; 6: 1, \mathrm{v} / \mathrm{v}$ ) to 
afford compound 16 as a white foam (5.0 g, 80\%). ${ }^{1} \mathrm{H}$ NMR (300 $\left.\mathrm{MHz}, \mathrm{CDCl}_{3}\right): \delta 9.52(\mathrm{~s}, 1 \mathrm{H}, \mathrm{NH}), 8.62(\mathrm{~s}, 1 \mathrm{H}, \mathrm{H}-8), 8.28(\mathrm{~s}, 1 \mathrm{H}, \mathrm{H}-$ 2), 7.96-7.93 (m, $2 \mathrm{H}, \operatorname{ArH}), 7.70-7.67(\mathrm{~m}, 2 \mathrm{H}, \mathrm{ArH}), 7.53-7.29$ $(\mathrm{m}, 6 \mathrm{H}, \mathrm{ArH}), 6.49\left(\mathrm{dd}, J=7.0,2.1 \mathrm{~Hz}, 1 \mathrm{H}, \mathrm{H}-1^{\prime}\right), 5.69-5.65(\mathrm{~m}$, $\left.1 \mathrm{H}, \mathrm{H}-3^{\prime}\right), 4.41-4.30\left(\mathrm{~m}, 2 \mathrm{H}, \mathrm{H}-4^{\prime}\right), 2.98-2.80\left(\mathrm{~m}, 2 \mathrm{H}, \mathrm{H}-2^{\prime}\right) ;{ }^{13} \mathrm{C}$ NMR $\left(75 \mathrm{MHz}, \mathrm{CDCl}_{3}\right): \delta 165.5,164.9(\mathrm{COPh}), 152.4(\mathrm{C}-2), 151.5$ (C-4), 149.6 (C-6), 141.0 (C-8), 133.7, 133.5, 132.6, 129.3, 128.9, 128.7, 128.5, 127.9 (Ar-C), $123.6(\mathrm{C}-5), 85.1\left(\mathrm{C}-1^{\prime}\right), 80.0\left(\mathrm{C}-4^{\prime}\right)$, $73.8\left(\mathrm{C}-3^{\prime}\right)$, $38.5\left(\mathrm{C}-2^{\prime}\right)$; HRMS for $\mathrm{C}_{23} \mathrm{H}_{20} \mathrm{~N}_{5} \mathrm{O}_{4}[\mathrm{M}+\mathrm{H}]^{+}$calcd, 430.1510; found, 430.1515.

$1^{\prime} \alpha$-(N6-Benzoyladenin-9-yl)-2'-deoxy-L-threose (17). ${ }^{29}$ To a suspension of compound $16(4.5 \mathrm{~g}, 10.5 \mathrm{mmol})$ in THF/MeOH/ $\mathrm{H}_{2} \mathrm{O}(280 \mathrm{~mL}, 5: 4: 1)$ at $0{ }^{\circ} \mathrm{C}$ was added an ice-cold $1 \mathrm{~N}$ aq $\mathrm{NaOH}$ solution $(21 \mathrm{~mL}, 21.0 \mathrm{mmol})$. The reaction was stirred at $0{ }^{\circ} \mathrm{C}$ for another $2 \mathrm{~h}$, and then the solution was neutralized with a $1 \mathrm{~N} \mathrm{HCl}$ solution. The mixture was concentrated under reduced pressure. The residue was purified by silica gel chromatography (gradient DCM/ $\mathrm{MeOH}, 50: 1, \mathrm{v} / \mathrm{v} ; 30: 1, \mathrm{v} / \mathrm{v} ; 25: 1, \mathrm{v} / \mathrm{v})$ to afford compound 17 as a white solid (2.4 g, 71\%). ${ }^{1} \mathrm{H}$ NMR (300 MHz, DMSO- $\left.d_{6}\right): \delta 8.73$ (s, $1 \mathrm{H}, \mathrm{H}-8), 8.66$ (s, 1H, H-2), 8.07-8.03 (m, 2H, ArH), 7.66-7.51 (m, $2 \mathrm{H}, \mathrm{ArH}), 6.45\left(\mathrm{dd}, J=7.9,2.2 \mathrm{~Hz}, 1 \mathrm{H}, \mathrm{H}-1^{\prime}\right), 4.53-4.51(\mathrm{~m}, 1 \mathrm{H}, \mathrm{H}-$ $\left.3^{\prime}\right)$, 4.05-3.96 (m, 2H, H-4'), 2.75-2.66 (m, 1H, H-2'a), 2.41-2.36 $\left(\mathrm{m}, 1 \mathrm{H}, \mathrm{H}-2^{\prime} \mathrm{b}\right) ;{ }^{13} \mathrm{C}$ NMR $\left(75 \mathrm{MHz}, \mathrm{DMSO}-d_{6}\right): \delta 165.7(\mathrm{COPh})$, 151.7 (C-2), 151.3 (C-4), 150.6 (C-6), 142.9 (C-8), 133.8, 132.1, $128.3(\mathrm{Ar}-\mathrm{C}), 125.5(\mathrm{C}-5), 85.1\left(\mathrm{C}-1^{\prime}\right), 76.5\left(\mathrm{C}-4^{\prime}\right), 69.1\left(\mathrm{C}-3^{\prime}\right)$, $40.1\left(\mathrm{C}-2^{\prime}\right)$; HRMS for $\mathrm{C}_{16} \mathrm{H}_{16} \mathrm{~N}_{5} \mathrm{O}_{3}[\mathrm{M}+\mathrm{H}]^{+}$calcd, 326.1248; found, 326.1250 .

(p-Toluenesulfonyloxymethyl)phosphonic Acid Monoethyl Ester (19). Diethyl ( $p$-toluenesulfonyloxymethyl)phosphonate (3.00 g, 9.31 $\mathrm{mmol})$ was dissolved in $1 \mathrm{M} \mathrm{NaOH} / \mathrm{THF}(\mathrm{v} / \mathrm{v}=1 / 1,30 \mathrm{~mL})$ and stirred for $2 \mathrm{~h}$ at room temperature. The reaction mixture was extracted with ethyl acetate $(2 \times 50 \mathrm{~mL})$. The layers were separated and the $\mathrm{pH}$ of the aqueous layer was adjusted to 1 with $2 \mathrm{M} \mathrm{HCl}$. The aqueous layer was extracted three times with ethyl acetate $(3 \times 100$ $\mathrm{mL})$. The combined organic phases were dried over $\mathrm{NaSO}_{4}$ and concentrated under reduced pressure to give a crude residue, which was recrystallized from ethyl acetate/hexane to afford compound 19 as a colorless oil $(2.10 \mathrm{~g}, 80 \%) .{ }^{1} \mathrm{H}$ NMR $\left(300 \mathrm{MHz}, \mathrm{CD}_{3} \mathrm{OD}\right): \delta 7.82$ $(\mathrm{d}, J=8.4 \mathrm{~Hz}, 2 \mathrm{H}, \operatorname{ArH}), 7.46(\mathrm{~d}, J=8.0 \mathrm{~Hz}, 2 \mathrm{H}, \mathrm{ArH}), 4.17(\mathrm{~d}, J=$ $\left.10.0 \mathrm{~Hz}, 2 \mathrm{H}, \mathrm{PCH}_{2}\right), 4.00-4.10\left(\mathrm{~m}, 2 \mathrm{H}, \mathrm{CH}_{2} \mathrm{CH}_{3}\right), 2.46(\mathrm{~s}, 3 \mathrm{H}$, $\left.\mathrm{CH}_{3} \mathrm{Ph}\right), 1.26\left(\mathrm{t}, J=7.0 \mathrm{~Hz}, 3 \mathrm{H}, \mathrm{CH}_{2} \mathrm{CH}_{3}\right) ;{ }^{13} \mathrm{C}$ NMR $(75 \mathrm{MHz}$, $\left.\mathrm{CD}_{3} \mathrm{OD}\right): \delta 147.1(\mathrm{Ar}-\mathrm{C}), 131.2(\mathrm{Ar}-\mathrm{C}), 129.3(\mathrm{Ar}-\mathrm{C}), 63.2(\mathrm{~d}$, $\left.{ }^{1} J_{\mathrm{P}, \mathrm{C}}=165.0 \mathrm{~Hz}, \mathrm{PCH}_{2}\right), 64.0\left(\mathrm{~d},{ }^{2} J_{\mathrm{P}, \mathrm{C}}=6.1 \mathrm{~Hz}, \mathrm{CH}_{2} \mathrm{CH}_{3}\right), 21.6$ $\left(\mathrm{CH}_{3} \mathrm{Ph}\right), 16.7\left(\mathrm{~d},{ }^{3} \mathrm{~J}_{\mathrm{P}, \mathrm{C}}=6.1 \mathrm{~Hz}, \mathrm{CH}_{2} \mathrm{CH}_{3}\right) ;{ }^{31} \mathrm{P} \mathrm{NMR}(121 \mathrm{MHz}$, $\mathrm{CD}_{3} \mathrm{OD}$ ): 13.9; HRMS for $\mathrm{C}_{10} \mathrm{H}_{14} \mathrm{O}_{6} \mathrm{PS}[\mathrm{M}-\mathrm{H}]^{-}$calcd, 293.0254; found, 293.0293.

1' $\alpha$-(Adenin-9-yl)-2' -deoxy-3'-O-monoethylphosphonomethyl-Lthreose (20). To a solution of compound $17(500 \mathrm{mg}, 1.54 \mathrm{mmol})$ and compound $19(900 \mathrm{mg}, 3.07 \mathrm{mmol})$ in anhydrous DMF $(50 \mathrm{~mL})$ was added $\mathrm{NaH}(60 \%$ in mineral oil, $290 \mathrm{mg}, 7.68 \mathrm{mmol})$ at $0{ }^{\circ} \mathrm{C}$. The reaction mixture was warmed to room temperature and stirred for $12 \mathrm{~h}$. The reaction was quenched with a $0.1 \mathrm{M} \mathrm{HCl}$ solution, and was subsequently concentrated under reduced pressure. The residue was dissolved in a $30 \%$ methanolic ammonia solution $(100 \mathrm{~mL})$ and stirred at room temperature for $12 \mathrm{~h}$. After removal of all the volatiles, the residue was purified by silica gel chromatography (gradient acetone $/ \mathrm{H}_{2} \mathrm{O} / \mathrm{Et}_{3} \mathrm{~N}, 20: 1: 1, \mathrm{v} / \mathrm{v} / \mathrm{v} ; 15: 1: 1, \mathrm{v} / \mathrm{v} / \mathrm{v} ; 10: 1: 1, \mathrm{v} / \mathrm{v} / \mathrm{v}$; $8: 1: 1, \mathrm{v} / \mathrm{v} / \mathrm{v})$ to afford compound $20(420 \mathrm{mg}, 80 \%)$ as a colorless foam. ${ }^{1} \mathrm{H}$ NMR (300 MHz, $\left.\mathrm{D}_{2} \mathrm{O}\right): \delta 8.37(\mathrm{~s}, 1 \mathrm{H}, \mathrm{H}-8), 8.13(\mathrm{~s}, 1 \mathrm{H}$, $\mathrm{H}-2), 6.33$ (dd, $\left.J=7.3,2.2 \mathrm{~Hz}, 1 \mathrm{H}, \mathrm{H}-1^{\prime}\right), 4.43-4.33\left(\mathrm{~m}, 2 \mathrm{H}, \mathrm{H}-3^{\prime}\right.$, $\left.\mathrm{H}-4^{\prime} \mathrm{a}\right), 4.07$ (dd, $\left.J=10.5,3.9 \mathrm{~Hz}, 1 \mathrm{H}, \mathrm{H}-4^{\prime} \mathrm{b}\right), 3.80-3.52(\mathrm{~m}, 4 \mathrm{H}$, $\left.\mathrm{PCH}_{2}, \mathrm{CH}_{2} \mathrm{CH}_{3}\right), 2.77-2.62\left(\mathrm{~m}, 2 \mathrm{H}, \mathrm{H}-2^{\prime}\right), 1.08(\mathrm{t}, J=7.1 \mathrm{~Hz}, 3 \mathrm{H}$, $\left.\mathrm{CH}_{2} \mathrm{CH}_{3}\right) ;{ }^{13} \mathrm{C}$ NMR $\left(75 \mathrm{MHz}, \mathrm{D}_{2} \mathrm{O}\right): \delta 155.2(\mathrm{C}-6), 152.2(\mathrm{C}-2)$, 148.3 (C-4), 141.2 (C-5), 140.6 (C-8), 118.3 (C-5), 83.9 (C-1), 80.0 $\left(\mathrm{d},{ }^{3} J_{\mathrm{P}, \mathrm{C}}=13.1 \mathrm{~Hz}, \mathrm{C}-3^{\prime}\right), 73.8\left(\mathrm{C}-4^{\prime}\right), 63.7\left(\mathrm{~d},{ }^{1} J_{\mathrm{P}, \mathrm{C}}=158.8 \mathrm{~Hz}\right.$, $\left.\mathrm{PCH}_{2}\right), 61.1,61.0\left(\mathrm{CH}_{2} \mathrm{CH}_{3}\right), 37.1\left(\mathrm{C}-2^{\prime}\right), 15.8,15.7\left(\mathrm{CH}_{2} \mathrm{CH}_{3}\right) ;{ }^{31} \mathrm{P}$ NMR (121 MHz, $\left.\mathrm{D}_{2} \mathrm{O}\right): 17.3$; HRMS for $\mathrm{C}_{12} \mathrm{H}_{17} \mathrm{~N}_{5} \mathrm{O}_{5} \mathrm{P}[\mathrm{M}-\mathrm{H}]^{-}$ calcd, 342.0973; found, 342.0970.

$1^{\prime} \alpha$-(Adenin-9-yl)-2'-deoxy-3'-O-phosphonomethyl-L-threose Triethylammonium Salt (PMDTA, 21). To a solution of compound
20 (540 mg, $1.57 \mathrm{mmol})$ and 2,6-lutidine $(2.90 \mathrm{~mL}, 25.2 \mathrm{mmol})$ in dry $\mathrm{CH}_{3} \mathrm{CN}(20 \mathrm{~mL})$ was added bromotrimethylsilane $(1.70 \mathrm{~mL}, 12.6$ $\mathrm{mmol})$ at $0{ }^{\circ} \mathrm{C}$. The reaction mixture was stirred at room temperature overnight and quenched with a $1.0 \mathrm{M}$ TEAB solution. After removal of all the volatiles under reduced pressure, the remaining residue was purified by silica gel column chromatography (gradient acetone/ $\left.\mathrm{H}_{2} \mathrm{O} / \mathrm{Et}_{3} \mathrm{~N}, 8: 1: 1, \mathrm{v} / \mathrm{v} / \mathrm{v} ; 5: 1: 1, \mathrm{v} / \mathrm{v} / \mathrm{v}, 4: 1: 1, \mathrm{v} / \mathrm{v} / \mathrm{v}\right)$ to afford compound 21 (500 mg, 70\%) as a white foam. Spectroscopic data were in agreement with a previous report. ${ }^{9}$

$1^{\prime}$ - $\alpha$-(Adenin-9-yl)-2'-deoxy-3'-O-\{[N-(diisoamyl-L-aspartate) $]$ (phenoxy)methylphosphonoamidate\}-L-threose (1). Compound 21 $(540 \mathrm{mg}, 1.71 \mathrm{mmol})$ was mixed with L-aspartic acid isoamyl diester $\mathrm{HCl}$ salt $(800 \mathrm{mg}, 2.57 \mathrm{mmol})$ and phenol $(710 \mathrm{mg}$, $7.54 \mathrm{mmol})$ in anhydrous pyridine $(30 \mathrm{~mL})$. Then, $\mathrm{Et}_{3} \mathrm{~N}(2.2 \mathrm{~mL})$ was added and the mixture was stirred at $60{ }^{\circ} \mathrm{C}$ under a nitrogen atmosphere for $15-$ $20 \mathrm{~min} .2,2^{\prime}$-Dithiodipyridine $(1.90 \mathrm{~g}, 8.57 \mathrm{mmol})$ was mixed in a separate flask with $\mathrm{PPh}_{3}(2.25 \mathrm{~g}, 8.57 \mathrm{mmol})$ in anhydrous pyridine $(10 \mathrm{~mL})$ and the resulting mixture was stirred for $10-15 \mathrm{~min}$ to give a clear light-yellow solution. This solution was then added to the above solution and the combined mixture was stirred at $60^{\circ} \mathrm{C}$ for $12 \mathrm{~h}$. The mixture was then concentrated under reduced pressure to give a residue that was redissolved in EtOAc. This solution was washed with saturated aq $\mathrm{NaHCO}_{3}$ and brine, the organic layer was separated, dried over $\mathrm{Na}_{2} \mathrm{SO}_{4}$, filtered, and concentrated under reduced pressure. The crude residue was purified by silica gel chromatography (gradient $\mathrm{DCM} / \mathrm{MeOH}, 60: 1, \mathrm{v} / \mathrm{v}, 30: 1, \mathrm{v} / \mathrm{v})$ to give the desired phosphonamidate 1 in pure form $(750 \mathrm{mg}, 66 \%)$ as a mixture of $\mathrm{P}$ $(S)$ and $\mathrm{P}(R)$ isomers. Spectroscopic data were in agreement with a previous report. ${ }^{10}$

In Vitro Evaluation against an Entecavir Drug-Resistant HBV Strain. Adenovectors AdH294-WT and AdH294-7LR harboring HBV replicating wild-type (genotype D, accession\# V01460) and ETV-resistant variant, respectively, were generated using Viral-Power System (Invitrogen, cat\# K4930). Briefly, HBV replicons under the drive of the tet-CMV promoter were cloned into a pENTRY4 shuttle plasmid expressing tetracycline transactivator (tTA). ETV-resistant mutations (rtL180M + rtT184G + S202I + M204V) were introduced into HBV wild-type replicon by point mutagenesis. ${ }^{30}$ Cloned shuttle plasmids were verified with DNA sequencing and recombined with the pDESTINY vector. Adenoviruses were then packaged in 293A cells and viral titers were determined with qPCR.

HepG2 cells (ATCC, cat\# HB8065) were cultured in Dulbecco's modified Eagle's medium (DMEM)/F12 containing 10\% fetal bovine serum and $100 \mathrm{U} / \mathrm{mL}$ penicillin plus $100 \mu \mathrm{g} / \mathrm{mL}$ streptomycin. When cells reached $95 \%$ confluence, adenoviruses were inoculated into the culture medium at a multiplicity of infection of 500. Antiviral treatment with ETV, TAF, and compound 1 was initiated $8 \mathrm{~h}$ post adenovirus infection. Medium was changed every two days and cells were harvested 5 days after drug treatment. HBV replicative intermediate DNA was extracted as previously described. ${ }^{31}$ Briefly, infected HepG2 cells were lysed in core DNA extraction buffer containing $10 \mathrm{mM}$ Tris- $\mathrm{HCl}, \mathrm{pH} 8.0,1 \mathrm{mM}$ EDTA, $100 \mathrm{mM} \mathrm{NaCl}$, $1 \%$ NP40, and $8 \%$ sucrose. Cell debris and nuclei were removed by centrifugation. The supernatant was mixed with PEG-8000 to a final concentration of $9 \%$ and placed on ice for $2 \mathrm{~h}$. Capsidated DNA was pelleted by centrifugation at $10,000 \mathrm{rpm}$ for $4 \mathrm{~min}$ at $4{ }^{\circ} \mathrm{C}$, followed by Proteinase $\mathrm{K}$ digestion, phenol/chloroform extraction, and isopropanol precipitation. Purified viral DNA was resolved in $1.5 \%$ agarose gel, blotted onto Hybond $\mathrm{N}+$ membrane (GE, cat\# RPN303B), and hybridized with a P32-labeled HBV probe.

Quantification of HBV cccDNA Using qPCR. The study was conducted at Southern Research under NIAID screening task order, using a previously published method ${ }^{32}$ and using HepDE19 cells. ${ }^{28}$ 50,000 HepDE19 cells were seeded in collagen-coated 24-well plates in the DMEM-F12 medium with $10 \%$ fetal bovine serum (FBS) and $0.1 \mu \mathrm{g} / \mathrm{mL}$ of doxycycline and incubated at a $37{ }^{\circ} \mathrm{C}$ incubator with $5 \%$ $\mathrm{CO}_{2}$. After $24 \mathrm{~h}$, the cell culture medium was replaced with serial dilutions of the compounds (6-point titration, triplicates per compound concentration) prepared in the DMEM-F12 medium with 10\% FBS without doxycycline (for induction of cccDNA 
synthesis). TAF was used as the positive control, while media alone was added to cells as a negative control (virus control, VC). Three and six days later, the culture medium was replaced with a fresh medium containing the appropriately diluted test compounds. Cells were harvested after 9 days and nuclear DNA was extracted using the NucleoSpin kit (cat\# 740952.250, Takara Bio), according to the kit protocol with couple of modifications as published previously. ${ }^{32}$ Extracted DNA was subjected to T5 exonuclease treatment (cat\# M0363, New England Biolabs, Ipswich, MA) for $60 \mathrm{~min}$ at $37{ }^{\circ} \mathrm{C}$, followed by inactivation at $70{ }^{\circ} \mathrm{C}$ for $20 \mathrm{~min}$. The resulting product was subjected to $\mathrm{HBV}$ cccDNA-specific qPCR using the primers HBV1523 5'GGGGCGACCTCTCTTTA3' and HBV1874 5'AGGCACAGCTTGGA-GGC3' and probe HBV1562 5'VIC-156 TTCTCATCTGCCGGA CCGTG-TAMRA3' labeled with VIC. PCR was performed using a QuantStudio 6 Real-Time PCR (qPCR) instrument (Thermo Fisher Scientific) with the following conditions; denaturing at $95{ }^{\circ} \mathrm{C}$ for $10 \mathrm{~min}, 45$ cycles with denaturing at $95{ }^{\circ} \mathrm{C}$ for $10 \mathrm{~s}$, annealing at $56^{\circ} \mathrm{C}$ for $30 \mathrm{~s}$, and extension at $60^{\circ} \mathrm{C}$ for $1 \mathrm{~min}$. A standard curve generated by using log dilutions of a gelpurified DNA standard was used to extrapolate and quantify the copy numbers of cccDNA in the test samples. Test samples without the T5 exonuclease treatment were subjected to $\beta$-actin $\mathrm{qPCR}$ using primers and a probe described previously ${ }^{33}$ as a measure of cytotoxicity of the compounds. qPCR was performed using the primers $\beta$-actin $\mathrm{F}$ 5'CCCAGC-CATGTACGTTGCTA3', $\beta$-actin R 5'TCACCGGAGTCCATCACGAT3 ${ }^{\prime}$, and $\beta$-actin probes Fam5'ACGCCTCTGGCCGTAC-CACTGG3'-Tamra. $\beta$-Actin PCR was performed using the following conditions; denaturing at $95{ }^{\circ} \mathrm{C}$ for 10 min, 45 cycles with denaturing at $95{ }^{\circ} \mathrm{C}$ for $10 \mathrm{~s}$, annealing and extension at $60{ }^{\circ} \mathrm{C}$ for $1 \mathrm{~min}$. Data analysis was performed by calculating the $\operatorname{cccDNA}$ and $\beta$-actin levels as a percentage of vehicle controls. The selectivity index $\left(\mathrm{SI}_{50}\right)$ is calculated as $\mathrm{CC}_{50} / \mathrm{EC}_{50}$.

Determination of Plasma Pharmacokinetics. Nine male C57BL/6 mice were administered orally with a solution (10\% DMSO, $10 \%$ Cremophor EL and $80 \%$ saline) of compound 1 at a dose of $6 \mathrm{mg} / \mathrm{kg}$. Blood samples (approximately $60 \mu \mathrm{L}$ ) were collected under light isoflurane anesthesia from retro orbital plexus from a set of three mice $0.25,0.5,1,2,4,6,8,12$, and $24 \mathrm{~h}$, postadministration. Plasma samples were separated by centrifugation of whole blood and stored below $-70 \pm 10^{\circ} \mathrm{C}$ until bioanalysis. All samples were processed for analysis by protein precipitation using acetonitrile and analyzed with the fit-for-purpose LC/MS/MS method (lower limit of quantification: $1.01 \mathrm{ng} / \mathrm{mL}$ ).

Antiviral Efficacy in a HBV Hydrodynamic Injection Mouse Model. Compound $\mathbf{1}$ was tested in an HBV DNA HDI mouse model as described by Wang et al. ${ }^{34}$ Briefly, one day after HDI of HBV 1.3 mer plasmid (day 0), six-week-old male C57BL/6 mice were administered orally once daily for 6 days with compound $\mathbf{1}$ and $\operatorname{TAF}(60,6$, and $0.6 \mathrm{mg} / \mathrm{kg} /$ day, $n=10$ animals per group). The vehicle-treated mice were gavaged with solution containing $10 \%$ DMSO, 10\% Cremophor, and $80 \%$ saline. ETV was also administered orally once daily at a single dose of $0.1 \mathrm{mg} / \mathrm{kg}$ as a positive control. The body weight measurements and blood collections from retro orbital plexus were conducted before compound treatment (day 0 ), and 2, 4, and 6 days post-treatment. Serum HBV DNA was extracted and its levels were then measured using a qPCR assay kit (Hunan Shengxiang Biotechnology Co., Ltd, China).

Toxicity Evaluation. The study was conducted at Sai Life Sciences Limited, Pune, India. In a 14 day repeated-dose toxicity study, 12 male and 12 female healthy C57BL/6 mice were randomly divided into eight groups (three per sex per group). Compound 1 was administered orally at $60 \mathrm{mg} / \mathrm{kg}$ once daily to C57BL/6 mice. Mice from the control group received 10\% DMSO, 10\% Cremophor EL, and $80 \%$ saline as vehicle. Treatment-related clinical signs of animals were observed daily. At day 15, blood samples were collected for analysis of hematology, pathology, and chemical parameters. In addition, organs such as liver, spleen, kidneys, heart, thymus, brain, testicles, epididymis, ovaries, and uterus were collected and weighted.

Ames Test. To test the mutagenicity of compound $\mathbf{1}$, an Ames test was carried out as described by Mortelmans and Zeiger. ${ }^{35}$ Briefly, the histidine-auxotrophic Salmonella typhimurium strains TA98, TA100, TA1535, TA1537, and TA1537 were grown overnight at $37^{\circ} \mathrm{C}$ in the LB medium with the appropriate antibiotic. To test the compound, both an overlay assay and droplet test were performed. For the overlay assay, $1.9 \mathrm{~mL}$ melted top agar $(0.6 \%$ agar, $0.6 \% \mathrm{NaCl}, 0.05$ $\mathrm{mM}$ histidine, and $0.05 \mathrm{mM}$ biotin) was mixed with $100 \mu \mathrm{L}$ of compound 1 or control solution and $\sim 5 \times 10^{6}$ bacteria, and this mixture was poured on glucose minimal agar plates. ${ }^{35}$ In the case of the droplet assay, $100 \mu \mathrm{L}$ of compound 1 or control solution was put upon solidified top agar with embedded bacteria. After incubation for $48-60 \mathrm{~h}$ at $37^{\circ} \mathrm{C}$, colonies were counted..

\section{ASSOCIATED CONTENT}

\section{Supporting Information}

The Supporting Information is available free of charge at https://pubs.acs.org/doi/10.1021/acs.jmedchem.0c01381.

NMR spectra of compounds $9,12,13,14,15,16,17$, 19, and 20; additional in vivo anti-HBV data and in vivo toxicity data; and molecular formula strings (PDF)

\section{AUTHOR INFORMATION}

\section{Corresponding Author}

Piet Herdewijn - Medicinal Chemistry, KU Leuven, Rega Institute for Medical Research, 3000 Leuven, Belgium; (1) orcid.org/0000-0003-3589-8503; Email: piet.herdewijn@kuleuven.be

\section{Authors}

Min Luo - Medicinal Chemistry, KU Leuven, Rega Institute for Medical Research, 3000 Leuven, Belgium

Shuo Wu - CAMS Key Laboratory of Antiviral Drug Research, Institute of Medicinal Biotechnology, Chinese Academy of Medical Sciences \& Peking Union Medical College, 100050 Beijing, China

Raj Kalkeri - Department of Infectious Disease Research, Southern Research Institute, Frederick, Maryland 21701, United States

Roger G. Ptak - Department of Infectious Disease Research, Southern Research Institute, Frederick, Maryland 21701, United States

Tianlun Zhou - Baruch S. Blumberg Institute, Doylestown, Pennsylvania 18902, United States

Lieve Van Mellaert - Department of Microbiology, Immunology and Transplantation, Laboratory of Molecular Bacteriology, KU Leuven, Rega Institute for Medical Research, 3000 Leuven, Belgium

Chuanmin Wang - Department of Infectious Diseases, Taihe Hospital, Hubei University of Medicine, Shiyan, Hubei 442000, China

Shrinivas G. Dumbre - Medicinal Chemistry, KU Leuven, Rega Institute for Medical Research, 3000 Leuven, Belgium

Timothy Block - Baruch S. Blumberg Institute, Doylestown, Pennsylvania 18902, United States

Elisabetta Groaz - Medicinal Chemistry, KU Leuven, Rega Institute for Medical Research, 3000 Leuven, Belgium

Steven De Jonghe - Department of Microbiology, Immunology and Transplantation, Laboratory of Virology and Chemotherapy, KU Leuven, Rega Institute for Medical Research, 3000 Leuven, Belgium; (1) orcid.org/0000-00023872-6558

Yuhuan Li - CAMS Key Laboratory of Antiviral Drug Research, Institute of Medicinal Biotechnology, Chinese Academy of Medical Sciences \& Peking Union Medical College, 100050 Beijing, China 
Complete contact information is available at:

https://pubs.acs.org/10.1021/acs.jmedchem.0c01381

\section{Author Contributions}

All authors have given approval to the final version of the manuscript.

\section{Funding}

HBV cccDNA assays were supported by the Division of Microbiology and Infectious Diseases (DMID), National Institute of Allergy and Infectious Diseases (NIAID), National Institutes of Health (NIH) under contract number 75N93019D00015 "In Vitro Assessment for Antimicrobial Activity" Task Order B01 "Comprehensive Viral Screening Panel”, under the direction of Dr. Mindy Davis as NIAID's Contracting Officer's Representative (COR), Ms. Amanda Ulloa as the Alternate COR, Dr. Roger Ptak as the Principal Investigator, and Dr. Raj Kalkeri as the Coinvestigator. Synthetic work was supported by the KU Leuven Research Fund via a C3 project (C32/17/045).

\section{Notes}

The authors declare no competing financial interest.

\section{ACKNOWLEDGMENTS}

We thank Sai Life Sciences Limited for plasma pharmacokinetic and toxicity evaluation. We are grateful to Prof. Jef Rozenski for recording the HRMS spectra and Luc Baudemprez for running the 2D NMR experiments. S.H. and Y.L. are grateful for financial support through The Drug Innovation Major Project (2018ZX09101003-003-003). R.G.P. and R.K. thank Ellen Nordgren for support in data processing and reporting for NIAID contract 75N93019D00015.

\section{ABBREVIATIONSPARA}

cccDNA, covalently closed circular DNA; ETV, entecavir; HBV, hepatitis B virus; HDI, hydrodynamic injection; PMDTA, phosphonomethoxydeoxythreosyl adenine; TAF, tenofovir alafenamide

\section{REFERENCES}

(1) World Health Organization. Global Hepatitis Report, 2017; WHO: Geneva, 2017.

(2) World Health Organization About Viral Hepatitis. 2019. WHO, https://www.who.int/hepatitis/about/en/ (accessed Nov 28, 2020).web

(3) Trépo, C.; Chan, H. L. Y.; Lok, A. Hepatitis B Virus Infection. Lancet 2014, 384, 2053-2063.

(4) Rouviere, C. P.; Dousson, C. B.; Tavis, J. E. HBV Replication Inhibitors. Antivir. Res. 2020, 179, 104815.

(5) Summers, J.; Mason, W. S. Replication of the Genome of a Hepatitis-B-Like Virus by Reverse Transcription of an RNA Intermediate. Cell 1982, 29, 403-415.

(6) Allweiss, L.; Dandri, M. The Role of cccDNA in HBV Maintenance. Viruses 2017, 9, 156.

(7) Nassal, M. HBV cccDNA: Viral Persistence Reservoir and Key Obstacle for a Cure of Chronic Hepatitis B. Gut 2015, 64, 19721984.

(8) Toti, K.; Renders, M.; Groaz, E.; Herdewijn, P.; Van Calenbergh, S. Nucleosides with Transposed Base or 4 '-Hydroxymethyl Moieties and Their Corresponding Oligonucleotides. Chem. Rev. 2015, 115, 13484-13525.

(9) Wu, T.; Froeyen, M.; Kempeneers, V.; Pannecouque, C.; Wang, J.; Busson, R.; De Clercq, E.; Herdewijn, P. Deoxythreosyl Phosphonate Nucleosides as Selective Anti-HIV Agents. J. Am. Chem. Soc. 2005, 127, 5056-5065.
(10) Liu, C.; Dumbre, S. G.; Pannecouque, C.; Huang, C.; Ptak, R. G.; Murray, M. G.; De Jonghe, S.; Herdewijn, P. Amidate Prodrugs of Deoxythreosyl Nucleoside Phosphonates as Dual Inhibitors of HIV and HBV Replication. J. Med. Chem. 2016, 59, 9513-9531.

(11) Murray, D. H.; Prokop, J. Synthesis of Tetrose Nucleosides I. Adenine Nucleosides of Erythrose and Threose. J. Pharm. Sci. 1967, $56,865-870$.

(12) Perel, J.; Dayton, P. A Convenient Synthesis of Crystalline LThreonolactone. J. Org. Chem. 1960, 25, 2044-2045.

(13) Isbell, H. S.; Frush, H. L. Oxidation of L-Ascorbic Acid by Hydrogen Peroxide: Preparation of L-Threonic Acid. Carbohydr. Res. 1979, 72, 301-304.

(14) Wei, C. C.; De Bernardo, S.; Tengi, J. P.; Borgese, J.; Weigele, M. Synthesis of Chiral $\beta$-Lactams Using L-Ascorbic Acid. J. Org. Chem. 1985, 50, 3462-3467.

(15) López, M. G.; Feather, M. S. The Production of Threose as a Degradation Product from L-Ascorbic Acid. J. Carbohydr. Chem. 1992, 11, 799-806.

(16) Schöning, K.-U.; Scholz, P.; Guntha, S.; Wu, X.; Krishnamurthy, R.; Eschenmoser, A. Chemical Etiology of Nucleic Acid Structure: the $\alpha$-Threofuranosyl-(3'-2') Oligonucleotide System. Science 2000, 290, 1347-1351.

(17) Schöning, K.-U.; Scholz, P.; Wu, X.; Guntha, S.; Delgado, G.; Krishnamurthy, R.; Eschenmoser, A. The $\alpha$-L-Threofuranosyl-( $\left.3^{\prime}-2^{\prime}\right)$ Oligonucleotide System ('TNA'): Synthesis and Pairing Properties. Helv. Chim. Acta 2002, 85, 4111-4153.

(18) Sau, S. P.; Fahmi, N. E.; Liao, J.-Y.; Bala, S.; Chaput, J. C. A Scalable Synthesis of $\alpha$-L-Threose Nucleic Acid Monomers. J. Org. Chem. 2016, 81, 2302-2307.

(19) Dumbre, S. G.; Jang, M.-Y.; Herdewijn, P. Synthesis of $\alpha$-LThreose Nucleoside Phosphonates via Regioselective Sugar Protection. J. Org. Chem. 2013, 78, 7137-7144.

(20) Gätzi, K.; Reichstein, T. L-Threonsäure-3-Methyläther Und LThreonsäure-2, 3-Dimethyläther. Helv. Chim. Acta 1938, 21, 195205 .

(21) Parameswar, A. R.; Hawkins, J. A.; Mydock, L. K.; Sands, M. S.; Demchenko, A. V. Concise Synthesis of the Unnatural Sphingosine and Psychosine Enantiomer. Eur. J. Org. Chem. 2010, 2010, 32693274.

(22) Wang, Y.-X.; Qi, S.-L.; Luan, Y.-X.; Han, X.-W.; Wang, S.; Chen, H.; Ye, M. Enantioselective Ni-Al Bimetallic Catalyzed exoSelective C-H Cyclization of Imidazoles with Alkenes. J. Am. Chem. Soc. 2018, 140, 5360-5364.

(23) Kamimura, A.; Miyazaki, K.; Suzuki, S.; Ishikawa, S.; Uno, H. Total Synthesis of ent-Calystegine B4 via Nitro-Michael/aldol Reaction. Org. Biomol. Chem. 2012, 10, 4362-4366.

(24) Henry, N.; Robertson, M. N.; Marquez, R. Fast and Efficient Synthesis of the Complete LL-Z1640-2 Framework. Tetrahedron Lett. 2007, 48, 6088-6091.

(25) Jang, M.-Y.; Froeyen, M.; Herdewijn, P. Regioselective 2'-ODebenzoylation of 2', 3'-Di-O-benzoyl Threose Nucleosides. Tetrahedron Lett. 2013, 54, 6084-6086.

(26) Guo, J.-T.; Guo, H. Metabolism and Function of Hepatitis B Virus cccDNA: Implications for the Development of cccDNATargeting Antiviral Therapeutics. Antivir. Res. 2015, 122, 91-100.

(27) Revill, P. A.; Chisari, F. V.; Block, J. M.; Dandri, M.; Gehring, A. J.; Guo, H.; Hu, J.; Kramvis, A.; Lampertico, P.; Janssen, H. L. A.; Levrero, M.; Li, W.; Liang, T. J.; Lim, S.-G.; Lu, F.; Penicaud, M. C.; Tavis, J. E.; Thimme, R.; Zoulim, F.; Arbuthnot, P.; Boonstra, A.; Chang, K.-M.; Chen, P.-J.; Glebe, D.; Guidotti, L. G.; Fellay, J.; Ferrari, C.; Jansen, L.; Lau, D. T. Y.; Lok, A. S.; Maini, M. K.; Mason, W.; Matthews, G.; Paraskevis, D.; Petersen, J.; Rehermann, B.; Shin, E.-C.; Thompson, A.; van Bömmel, F.; Wang, F.-S.; Watashi, K.; Yang, H.-C.; Yuan, Z.; Yuen, M.-F.; Block, T.; Miller, V.; Protzer, U.; Bréchot, C.; Locarnini, S.; Peters, M. G.; Schinazi, R. F. Global Scientific Strategy to Cure Hepatitis B. Lancet Gastroenterol. Hepatol. 2019, 4, 545-558.

(28) Guo, H.; Jiang, D.; Zhou, T.; Cuconati, A.; Block, T. M.; Guo, J.-T. Characterization of the Intracellular Deproteinized Relaxed 
Circular DNA of Hepatitis B Virus: An Intermediate of Covalently Closed Circular DNA formation. J. Virol. 2007, 81, 12472-12484.

(29) Bala, S.; Liao, J.-Y.; Zhang, L.; Tran, C. N.; Chim, N.; Chaput, J. C. Synthesis of 2'-Deoxy- $\alpha$-L-threofuranosyl Nucleoside Triphosphates. J. Org. Chem. 2018, 83, 8840-8850.

(30) Tacke, F.; Kroy, D. C. Treatment for Hepatitis B in Patients With Drug Resistance. Ann. Transl. Med. 2016, 4, 334.

(31) Zhou, T.; Block, T.; Liu, F.; Kondratowicz, A. S.; Sun, L.; Rawat, S.; Branson, J.; Guo, F.; Steuer, H. M.; Liang, H.; Bailey, L.; Moore, C.; Wang, X.; Cuconatti, A.; Gao, M.; Lee, A. C. H.; Harasym, T.; Chiu, T.; Gotchev, D.; Dorsey, B.; Rijnbrand, R.; Sofia, M. J. HBsAg mRNA Degradation Induced by a Dihydroquinolizinone Compound Depends on the HBV Posttranscriptional Regulatory Element. Antiviral Res. 2018, 149, 191-201.

(32) Qu, B.; Urban, S. Quantification of Hepatitis B Virus Covalently Closed Circular DNA in Infected Cell Culture Models by Quantitative PCR. Bio-Protoc. 2019, 9, No. e3202.

(33) Nyström, K.; Biller, M.; Grahn, A.; Lindh, M.; Larson, G.; Olofsson, S. Real Time PCR for Monitoring Regulation of Host Gene Expression in Herpes Simplex Virus Type 1-Infected Human Diploid Cells. J. Virol. Methods 2004, 118, 83-94.

(34) Wang, A.; Wu, S.; Tao, Z.; Li, X.; Lv, K.; Ma, C.; Li, Y.; Li, L.; Liu, M. Design, Synthesis, and Anti-HBV Activity of New Bis(l-amino acid) Ester Tenofovir Prodrugs. ACS Med. Chem. Lett. 2019, 10, 991995.

(35) Mortelmans, K.; Zeiger, E. The Ames Salmonella/Microsome Mutagenicity Assay. Mutat. Res. 2000, 455, 29-60. 